\title{
Damselfish Territoriality: Influence on Diadema Distribution and Implications for Coral Community Structure
}

\author{
Paul W. Sammarco ${ }^{1}$ and Ann H. Williams ${ }^{2}$ \\ ${ }^{1}$ Australian Institute of Marine Science, P.M.B. No. 3, Townsville M.S.O., Queensland 4810, Australia \\ ${ }^{2}$ Department of Zoology - Entomology, Auburn University, Auburn, Alabama 36830, USA
}

\begin{abstract}
Experiments were performed in Discovery Bay (Jamaica, W.I.) to determine the relationship between behavior of threespot damselfish Eupomacentrus planifrons Cuvier, and distribution of the common shallow-water echinoid Diadema antillarum Philippi. E planifrons actively excludes Diadema from its algal lawn, causing a distinct alteration in local distribution of Diadema on the reef. Physical attacks on the urchin were usually sustained for $\geqslant 5 \mathrm{~min}$. The damselfish's agonistic behavior occurred only during the day. Diadema densities were higher within algal lawns at night than during the day but were always significantly lower than the mean density outside. The size of the damselfish's algal lawn was positively correlated with damselfish density, implying that damselfish which occur in aggregations are able to defend larger territories together than they would when occurring alone. The impact of interactions between fishes, urchins and sessile epibenthos are predictable from experimental data derived from a concurrent study. E. planifrons territories are probably sites of locally high mortality in coral spat, particularly in Agaricia and Porites spp. This would result from competition for space with algae and encrusting epifauna. The algal lawns, however, may also represent refuges for other corals such as Favia fragum which are well-adapted to survive competition with other sessile epifauna as well as with algae. Thus, the algal lawns could represent discrete patches in the environment within which mortality of dominant species is high and that of rarer species is relatively low, causing an increase in the latter's representation in the benthic community. The net effect of this would be an overall increase in coral diversity within the community. This interpretation is consistent with hypotheses concerning the role of patch-formation in determining community structure.
\end{abstract}

\section{INTRODUCTION}

Territorial behaviour can greatly reduce the density of intruders within a territory (e.g. Dow, 1977; Williams, 1979). The damselfish Eupomacentrus planifrons Cuvier is one of the most aggressive territorial pomacentrids in the Caribbean (Robertson et al., 1976; Itzkowitz, 1979). It has been observed to defend successfully its territories against conspecifics, heterospecific fish, and certain benthic invertebrates - in particular Diadema antillarum Philippi (Kaufman, 1977; Williams, 1977, 1978, 1980). This urchin is known to be an important shallow-reef grazer (Ogden et al., 1973a, b,; Sammarco et al., 1974; Lawrence, 1975; Sammarco, 1977, 1980a, in press; Lawrence and Sammarco, in press). Interspecific interactions are common between pomacentrids and other fish and have been widely studied (Myrberg and Thresher, 1974; Sale, 1975; Thresher, 1976; and others), but only rarely have cases of a pomacentrid demonstrating aggression towards non-piscine members of the community been recorded (Albrecht, 1969; Clarke, 1970; Williams, 1977, 1978, 1980). Interphyletic interactions such as this have received little attention in behavioral ecology (Pearson, 1977).

Territorial populations are known to alter local community structure in the shallow reef environment. By excluding many herbivorous fish, some territorial damselfish allow algae to proliferate within their territories, causing an increase in biomass of algae and a shift in algal community structure (Ogden and Lobel, 1978; Lassuy, 1980; Montgomery, 1980a, b; Hixon and Brostoff, in press; Wilkinson and Sammarco, in press). This is particularly true of Eupomacentrus planifrons, 
the territories of which possess 5 times (to $40 \times$ ) as much algal biomass by wet weight (Brawley and Adey, 1977) or 1.7 times as much by dry weight (Williams, 1977, 1981) as areas outside their territories.

Vine (1974) has demonstrated that the aggressive behavior of Pomacentrus lividus and Acanthurus sohal affects not only the distribution of algae but also that of sessile epibenthic invertebrates such as spirorbid polychaetes. According to Potts (1977), Dischistodus perspicillatus can be responsible for mortality of adult colonies of the coral Acropora palifera in shallow water, and Kaufman (1977) demonstrated that Eupomacentrus planifrons has a similar effect on Acropora cervicornis.

Diadema antillarum is known to influence the structure of shallow reef communities on a much broader scale. Its grazing activities significantly alter algal community structure (Ogden et al., 1973a; Sammarco et al., 1974). In addition, it can control the success of settlement and survival in both juvenile and adult corals, significantly affecting coral species composition, abundance, and diversity (Sammarco, 1975, 1977 , 1980 a, in press). This effect is most dramatic at high densities where food is scarce and grazing intense.

If the agonism of Eupomacentrus planifrons is sufficiently intense to inhibit the grazing activities of Diadema antillarum within its territory, then a small patch within the habitat will have been formed which exhibits characteristics differing from those of surrounding community. Patch formation and small-scale disturbances of this sort are known to have significant effects on community structure (Grassle, 1973; Levin, 1974; Levin and Paine, 1974; Menge, 1976; Whittaker and Levin, 1977; Vance, in press).

Here we demonstrate that Eupomacentrus planifrons exerts a significant effect on the local distribution of Diadema antillarum. We also suggest that this alteration in distribution has important secondary effects on shallow-reef community structure, causing a shift in the success and pattern of recruitment in scleractinian corals.

\section{MATERIALS AND METHODS}

Experiments were performed in 3 sites within the area of Discovery Bay, Jamaica, W.I. $\left(77^{\circ} 24^{\prime} \mathrm{W}\right.$,

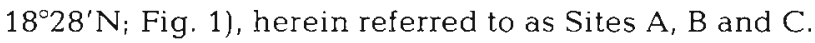
Site $A$ was a set of 2 lagoonal patch reefs - Crosby and Stills Reefs - in the southern portion of the bay, ranging in area from 250 to $5,800 \mathrm{~m}^{2}$ and in depth from 2 to $5 \mathrm{~m}$. These reefs were chosen for their conspicuously high densities of Diadema antillarum and Echinometra viridis (A. Agassiz) in comparison to densities observed on similar Caribbean patch reefs (e.g. Tague

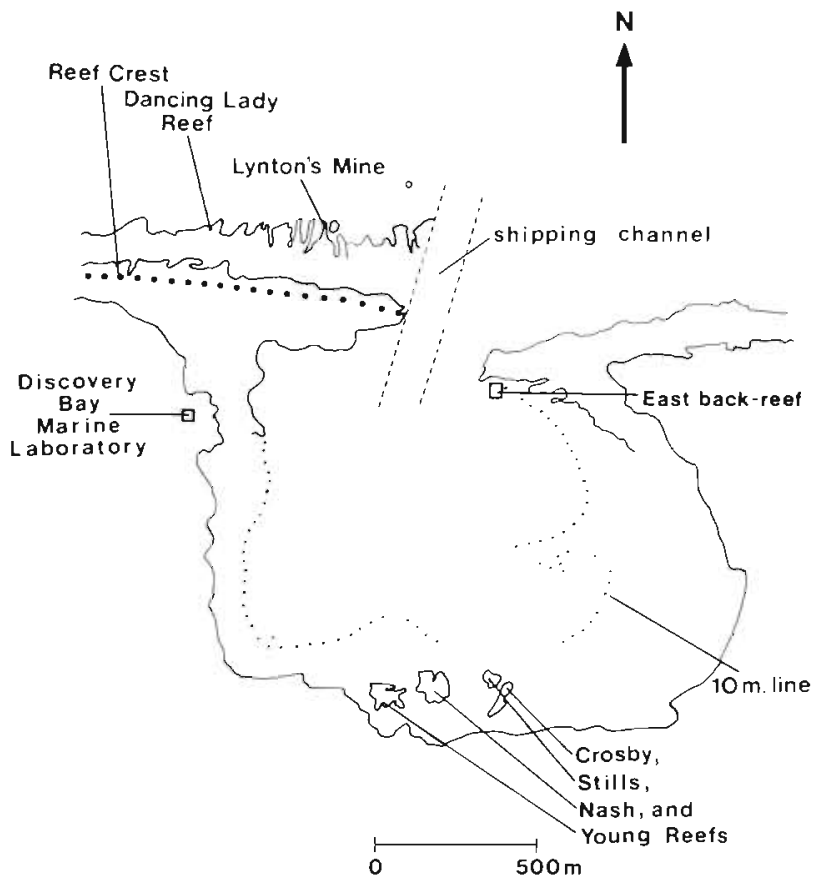

Fig. 1. Map of Discovery Bay, Jamaica, W.I. depicting study sites

Bay, St. Croix, U.S.V.I.; see Sammarco et al., 1974). The echinoids Lytechinus williamsi (Chesher) and Eucidaris tribuloides (Lamarck) were also present, although in much lower abundances. Site B was a backreef on the eastern side of the bay, 3 to $5 \mathrm{~m}$ in depth with a high abundance of threespot damselfish and a similar complement of echinoid species (Williams, 1978); it was characterized by the staghorn coral Acropora cervicornis. Site $C$ was located on the forereef at a depth of $15 \mathrm{~m}$, specifically Dancing Lady Reef and Lynton's Mine.

Baseline information of Diadema antillarum densities was collected at Sites $\mathrm{A}$ and $\mathrm{C}$ with $1 \mathrm{~m}^{2}$ quadrats placed along uniform linear transects. Site C was sampled during the day and at night; 10 to 20 evenly spaced quadrats were examined along each transect.

The Eupomacentrus planifrons populations were censused at Site A in April 1975 with the aid of belt transects $1 \mathrm{~m}$ in breadth. At least four $10 \mathrm{~m}$ transects were used and repeated 3 times each. The number of Diadema antillarum within the algal lawn of each damselfish territory was also recorded. The number of damselfish and urchins within 52 marked Acropora cervicornis patches of known dimensions at Site B were also recorded daily from August 1975 to July 1976.

Sizes of algal lawns were estimated by calculating surface area $\left(\mathrm{m}^{2}\right)$ from length and width measurements. Diadema antillarum density within territories was estimated by dividing the mean number of $D$. 
antillarum within territories by the mean size of Eupomacentrus planifrons territories and standardizing to no. $\mathrm{m}^{-2}$. In this way, any variation in size of algal lawn due to clumping of damselfish would be averaged out.

In order to test the hypothesis that differences in Diadema antillarum distribution were due to damselfish interference, urchins were experimentally added to damselfish algal lawns at Sites $A$ and $C$. The urchins were added by prodding to which they reacted with an alarm response (Snyder and Snyder, 1970), or by direct placement with the aid of a diver's hand-tool. The damselfish's response took the form of nipping and displays and was recorded as either positive or no response. Each individual was observed for $5 \mathrm{~min}$, and the duration of response was recorded. Observations were made on $>125$ damselfish at various times of the day, including dawn and evening periods and under new and full moon conditions (also see Williams, 1979).

All experiments were performed in the field with the aid of SCUBA.

\section{RESULTS}

Diadema antillarum densities were very high on Crosby Reef, intermediate on the forereef, and low within the algal lawns of the damselfish (Table 1). D. antillarum densities within algal lawns of damselfish territories on Dancing Lady Reef were significantly higher at night than during the day. However, $D$. antillarum densities within algal lawns were significantly lower than those outside in all cases observed.

Table 1. Densities of Diadema antillarum in no. individuals/ $\mathrm{m}^{2}$ inside and outside damselfish territories. Diurnal vs. nocturnal data also shown. Nocturnal Diadema densities within territories significantly higher than diurnal ones $(p<0.005$, Kruskal-Wallis Test) but significantly lower than nocturnal densities outside territories $(p<0.005)$

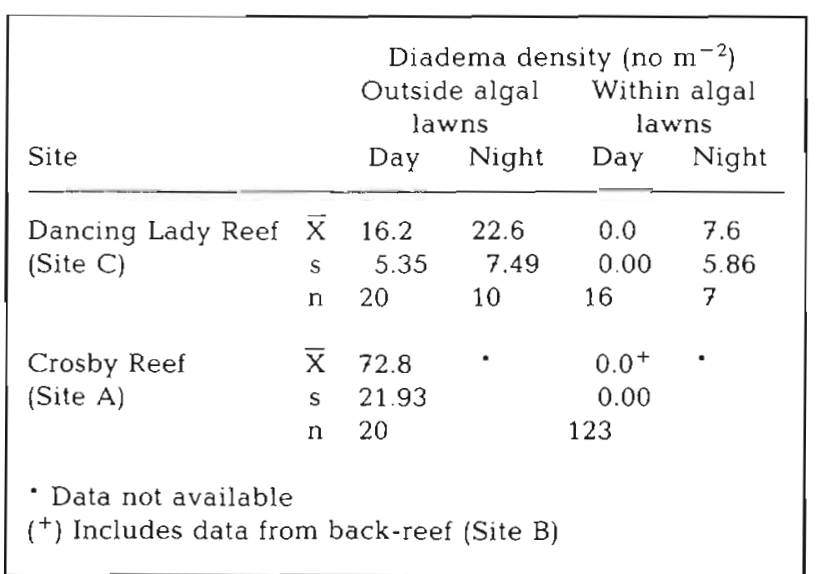

Similar supporting observations were made at the back-reef site.

Adult Eupomacentrus planifrons densities on Crosby and Stills Reefs were estimated to be $5.110 \mathrm{~m}^{-2}$ ( $\mathrm{s}=$ 3.06, $n=12$ ) and $7.2(s=2.00, n=24)$, respectively. Densities in the back-reef were $2.8 \mathrm{~m}^{-2}(s=1.38, n=$ $36)$, and algal lawns were estimated to cover an average of $0.19 \mathrm{~m}^{2}(s=0.18, n=36)$. This meant that the algal lawns of this damselfish accounted for $53 \%$ of the surface area at this site. A significant positive correlation was found between the density of damselfish and the size of their individual algal lawns (Fig. 2).

Each Diadema antillarum introduced into a damselfish territory immediately elicited an agonistic response from the fish, consisting of a lateral approach and a grasping of the spine with its mouth. It would then abruptly twist and sever the tip of the spine and

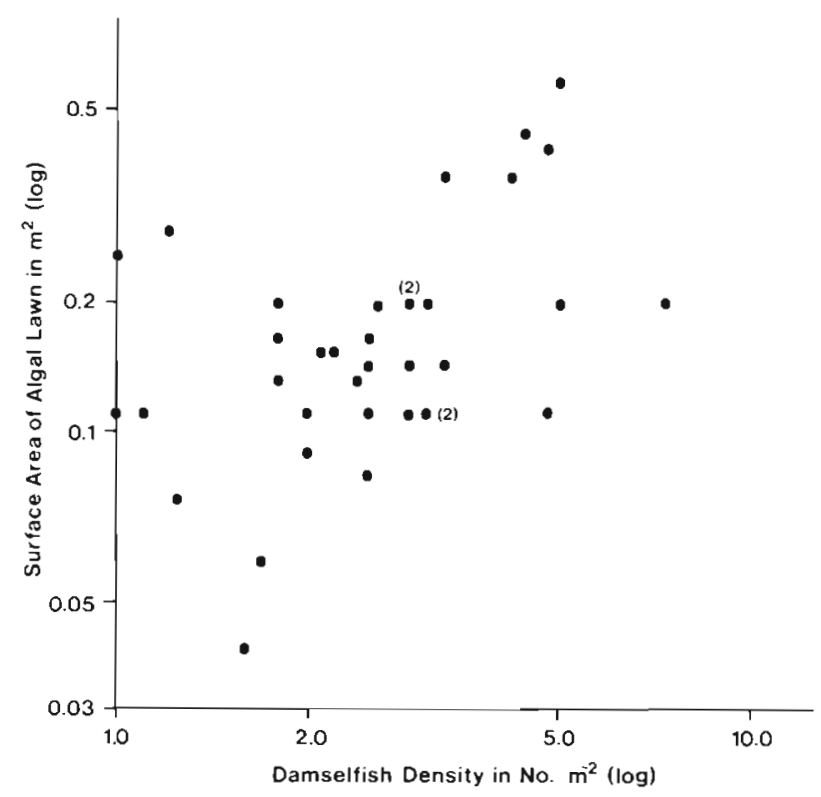

Fig. 2. Relationship between Eupomacentrus planifrons density and surface area of algal lawn within Acropora cervicornis patches (Site B). Significant positive correlation ( $\mathrm{r}=$ $0.49, \mathrm{p}<0.01$, Pearson's correlation analysis). Multiple points represented in parentheses

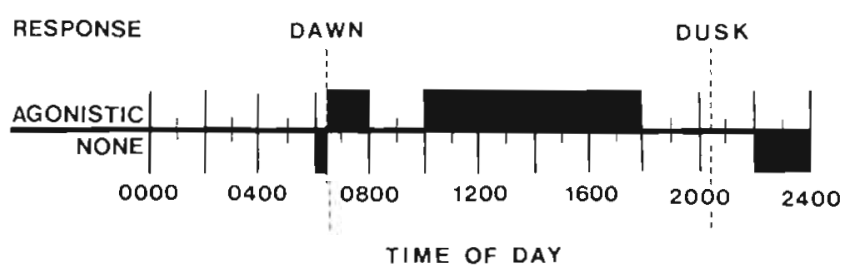

Fig. 3. Diurnal pattern of agonistic responses elicited from Eupomacentrus planifrons by Diadema antillarum. Urchins were experimentally introduced into territories. Data presented only for those hours specifically tested. $N>100$ individual damselfish, 1 trial per individual 
Table 2. Diurnal vs. nocturnal responsiveness of E. planifrons to intrusion by Diaderna into its territory. Frequency of diurnal response significantly greater than nocturnal responses $(p<0.005$, Model II $2 \times 2$ contingency G-test)

\begin{tabular}{lrcr|}
\hline Response & Day & Evening & Total \\
\hline Agnostic response & 102 & 0 & 102 \\
No. response & 1 & 16 & 17 \\
Total & 103 & 16 & 119 \\
\hline
\end{tabular}

swim away, releasing it. Each attack was short in duration $(\overline{\mathrm{X}}=3 \mathrm{~s} ; \mathrm{s}=1.6, n=20)$. The attacks were repeated in rapid succession randomly over the urchin's test. After continuous harassment, the echinoid usually exhibited a strong, randomly directed alarm response and quickly left the territory.

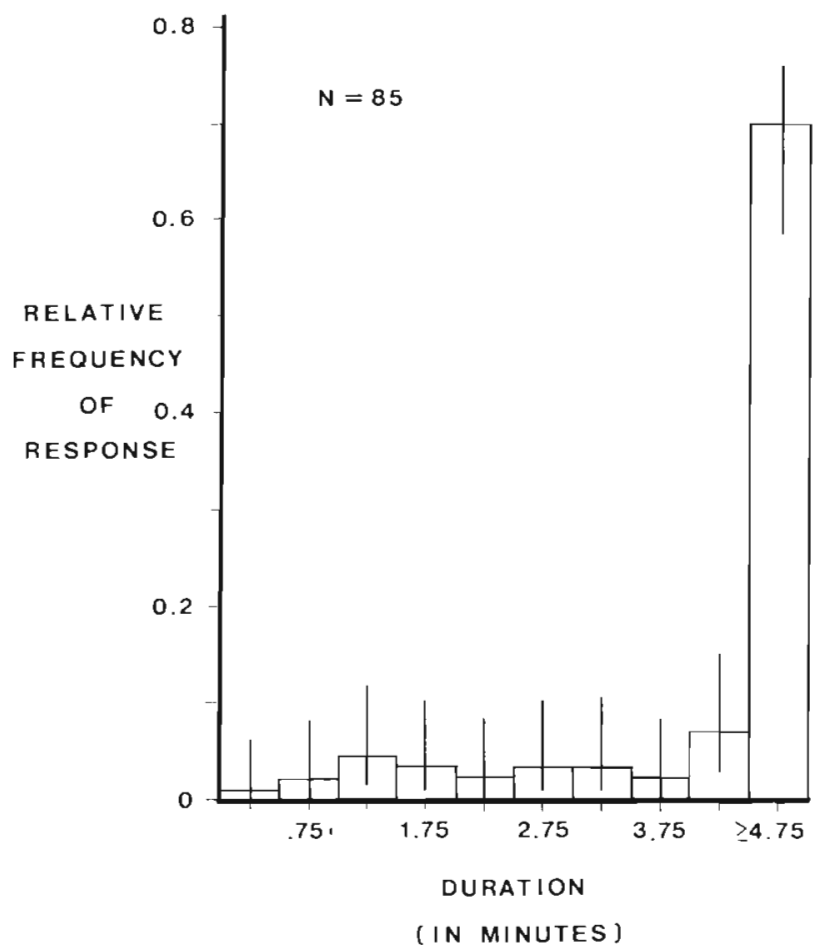

Fig. 4. Relative frequency distribution of duration of agonistic response in Eupomacentrus planifrons against Diadema antillarum with $95 \%$ confidence intervals

When tested, the fish responded aggressively only during daylight hours (post-dawn, pre-dusk; Fig. 3, Table 2) with approximately $70 \%$ of the timed responses continuing for $>5 \mathrm{~min}$ (Fig. 4). In contrast to their daytime habits, the damselfish were consistently timid during the evening hours, irrespective of phase of the moon and resultant light levels.

\section{DISCUSSION}

Eupomacentrus planifrons actively defends its territory against Diadema antillarum only during the day. Similar observations have been made on congeners such as E. partitus (Myrberg, 1972) and E. fuscus (Itzkowitz, pers. comm.), as well as on other pomacentrids (e.g. Ebeling and Bray, 1976). For a general discussion of diurnal vs. nocturnal activities in fish, see Hobson (1965, 1972) and Collette and Talbot (1972).

The removal of all Diadema antillarum by the fish tested here indicates that threespot damselfish are capable of clearing these urchins from their lawns and creating the observed heterogeneity in their distribution. Spatial partitioning of Acropora cervicornis patches by both $D$. antillarum and Echinometra viridis has been attributable partially to threespot interference with these urchins (Williams, 1979).

The density of damselfish may also affect the scope of grazing by Diadema antillarum within Acropora cervicornis patches. The positive correlation between algal lawn size per territory and damselfish density implies that damselfish occurring in higher densities or in aggregations have a positively synergistic effect on the area of substrate which is defended from grazing fish. This is implied from the data collected here but requires experimental verification.

The urchin is primarily a nocturnal grazer (Lewis, 1964; Randall et al., 1964) but also feeds during the day when occurring at densities such as those found on Crosby Reef (P.W.S., pers. obs.). Once territorial defence has been relaxed in an area, one might expect an intruder to take advantage of this ready access to food, particularly if it is in short supply. Echinoids are known to have well developed chemosensory powers (Leighton, 1966; Garnick, 1978). Diadema antillarum in particular is known to respond to chemical stimuli involving repulsion from predated conspecifics (Snyder and Snyder, 1970) and attraction to algae (Sammarco, 1972; Carpenter, 1979). Despite this, Eupomacentrus planifrons territories did not experience a high influx of $D$. antillarum during the early evening, the urchin's peak period of activity (Ogden et al., 1973a, b; Smith, 1975). D. antillarum densities were higher on algal mats within the territories at night than during the day but still remained well below the surrounding natural density.

Eupomacentrus planifrons is not $100 \%$ effective at excluding Diadema antillarum from its territories. Averaged over a 24 -h period, the $D$. antillarum density within algal lawns is not $0 \mathrm{~m}^{-2}$ but slightly higher. This is important in light of the effects of the grazing activities of $D$. antillarum on coral community structure. Earlier studies demonstrated that reduction in the density of $D$. antillarum can result in an increase in 
coral spat diversity under primary succession conditions (Sammarco, 1975, 1977, 1980a). Through grazing, the urchins deter successful coral recruitment in a species-specific manner. They also strongly influence competitive outcomes between juvenile corals and other epibiota by changing the array of competitors with which the spat must compete for space. Optimal conditions for settlement, survival, growth, and competitive success in such coral genera as Agaricia and Porites occur at intermediate $D$. antillarum densities. Favia fragum, on the other hand, is an excellent competitor against algae and thrives at negligible grazing intensities (Sammarco, 1977, 1980a). The sum of these effects results in an increase in spat diversity (as measured by $\mathrm{H}^{\prime}$; see Pielou, 1967, 1969, 1975) in the absence of grazing under primary succession conditions. These conditions of reduced grazing on newly provided primary substrate - freshly killed coral - are created by the colonization of E. planifrons and its defense of the area (Kaufman, 1977). This has also been demonstrated to occur in other damselfish (Potts, 1977).

Fish grazing is not entirely absent within these territories. Eupomacentrus planifrons is itself an omnivore, browsing on algae as well as sessile and vagile invertebrates within its algal mat (Randall, 1967; Robertson et al., 1976). The impact of this grazing on the benthic community, however, is probably trivial in comparison to that of the urchins (Williams, 1981). Recent experimentation has demonstrated that fish grazing in Discovery Bay has little if any impact on success of coral settlement in the absence of echinoids (Sammarco, in press).

Territoriality by Hemiglyphidodon plagiometopon Bleeker (Pomacentridae) on the Great Barrier Reef has been correlated with an increase in local diversity of adult corals (Sammarco, 1980b, and work in progress). In addition, the reduced grazing characteristic of these territories has been experimentally demonstrated to cause an increase in the number of coral genera within the algal lawns of this fish (Sammarco, 1980b; Sammarco and Carleton, in press).

Eupomacentrus planifrons may affect coral community structure in a similar manner, both at the adult level and at the earliest stages of succession. E. planifrons territories may remain distinct for extended periods of time, for long-term serial territories (those re-invaded by a series of males through time) are common in $E$. planifrons (Itzkowitz, pers. comm.). The territories of another pomacentrid, Hypsopops rubicunda, common in eastern Pacific waters, have been observed to be maintained for $>13$ y (Clarke, 1970).

Considering the density of these fish on the reef and the area of their algal lawns, their potential impact becomes evident. In areas such as the back reef, over
$50 \%$ of the reef surface is under the influence of Eupomacentrus planifrons. We suggest here that their indirect effect on community structure may be an important factor contributing to the maintenance of high coral diversity on the reef.

\section{CONCLUSIONS}

(1) Eupomacentrus planifrons defends its territory against Diadema antillarum through attacks usually sustained for $\geqslant 5 \mathrm{~min}$. Local urchin distribution is affected, causing patches where grazing by $D$. antillarum is reduced.

(2) Territorial defense occurs only during daylight hours; the lack of nocturnal defense is unaffected by changes in lunar phase.

(3) Densities of Diadema antillarum within the algal lawns of threespot damselfish are always lower than the natural density outside.

(4) Size of algal lawns within territories of threespot damselfish is positively correlated with damselfish density.

(5) Areas within Eupomacentrus planifrons territories represent local patches in the environment where grazing by Diadema antillarum is reduced and stands of algae are maintained. This, in turn, may influence coral community structure by causing the mortality of some adult corals, susceptible to overgrowth by algae while allowing others which are better competitors for space under these conditions to survive.

Acknowledgements. We thank J. S. Levinton and M. Itzkowitz for encouragement and advice, and G. C. Williams, G. J. Hechtel, D. J. Futuyma, B. D. Keller and J. B. C. Jackson for helpful discussions during the study. The manuscript has benefited from comments by J. S. Bunt, M. J. Risk, B. D. Sustare, and D. M. Williams. Our gratitude extends to the staff and visiting investigators of the Discovery Bay Marine Laboratory for aid during the study, and to the Australian Institute of Marine Science for assistance in preparation of the manuscript.

Support for the project was derived from the Biological Oceanography Section of the National Science Foundation in the form of pre-doctoral dissertation grants \#31848A (to P.W.S.) and OCE 76-02051 (to A.H.W.). Supplementary support was received from the Department of Ecology and Evolution, the Office of International Studies, and the Graduate School of the State University of New York at Stony Brook (to P.W.S.), as well as from the Marine Science Curriculum and Department of Zoology, The University of North Carolina at Chapel Hill (to A.H.W.). Contrib. No. 400, Ecology and Evolution, S.U.N.Y. at Stony Brook; No. 257, Discovery Bay Marine Lab. 


\section{LITERATURE CITED}

Albrecht, H. (1969). Behavior of four species of Atlantic damselfishes from Columbia, South America (Abudefduf saxatalis, A. taurus, Chromis multilineata, C. cyanea; Pisces, Pomacentridae). Z. Tierpsychol. 26: 622-676

Brawley, S. H., Adey, W. H. (1977). Territorial behaviour of threespot damselfish (Eupomacentrus planifrons) increases reef algal biomass and productivity. Environ. Biol. Fishes 2(1): 45-51

Carpenter, R. C. (1979). The foraging strategy of Diadema antillarum (Philippi) (Echinodermata: Echinoidea). M. Sc. thesis, University of the Pacific

Clarke, T. A. (1970). Territorial behavior and population dynamics of a pomacentrid fish, the garibaldi, Hypsopops rubicunda (Pomacentridae). Ecol. Monogr. 40: 189-212

Collette, B. B., Talbot, F. H. (1972). Activity patterns of coral reef fishes with emphasis on nocturnal-diurnal changeover. In: Collette, B. B., Earle, S. A. (eds.) Results of the Tektite Program: ecology of coral reef fishes. Bull. Los Angeles City Nat. Hist. Mus. Sci. 14: 98-124

Dow, D. D. (1977). Indiscriminate interspecific aggression leading to almost sole occupancy of space by a single species of bird. Emu 77(3): 115-121

Ebeling, A. W., Bray, R. N. (1976). Day versus night activity of reef fishes in a kelp forest off Santa Barbara, Calif. Fish. Bull. U.S. 74(4): 703-717

Garnick, E. (1978). Behavioral ecology of Strongylocentrotus droebachiensis (Mullen) (Echinodermata: Echinoidea): aggregating behavior and chemotaxis. Oecologia (Berl.) $37(1): 77-84$

Grassle, J. F. (1973). Variety in coral reef communities. In: Jones, O. A., Endean, R. (eds.) Biology and geology of coral reefs, Vol. 2. Academic Press, New York, pp. $247-270$

Hixon, M. A., Brostoff, W. N. (in press). Fish grazing and community structure of Hawaiian reef algae. In: Gomez, E. (ed.) The Reef and Man, Proc. Fourth Int. Coral Reef Symp., Manila, May 1981

Hobson, E. S. (1965). Diumal-nocturnal activity of some inshore fishes in the Gulf of California. Copeia 3: 291-302

Hobson, E. S. (1972). Activity of Hawaiian reef fishes during the evening and morning transitions between daylight and darkness. Fish. Bull. U.S. 70: 715-740

Itzkowitz, M. (1979). Territorial tactics and habitat quality. Am. Nat. 114(4): 585-590

Kaufman, L. (1977). The threespot damselfish: effects on benthic biota of Caribbean coral reefs. Proc. Third Int. Coral Reef Symp., Miami, Florida, pp. 559-564

Lassuy, D. R. (1980). Effects of farming behavior by Eupomacentrus lividus and Hemiglyphidodon plagiometopon on algal community structure. Bull. mar. Sci. 30: 304-312

Lawrence, J. M. (1975). On the relationships between marine plants and sea urchins. Oceanogr mar. biol. A. Rev. 13: 213-286

Lawrence, J. M., Sammarco, P. W. (in press). Effect of feeding on the environment: Echinoidea. In: Jangoux, M., Lawrence, J. M. (eds.) Echinoderm nutrition. A. A. Balkema Press, Rotterdam

Leighton, D. L. (1966). Grazing activities of benthic invertebrates in kelp beds. In: North, W. J. (ed.) The biology of giant kelp beds (Macrocystis) in California. J. Cramer Publ., Lehre, F.R.G., Beih. Nova Hedwigia 32: 421-453

Levin, S. A. (1974). Dispersion and population interaction. Am. Nat. 108: 207-228

Levin, S. A., Paine, R. T. (1974). Disturbance, patch formation, and community structure. Proc. natn. Acad. Sci. U.S.A. 71 : $2744-2747$

Lewis, J. B. (1964). Feeding and digestion in the tropical sea urchin Diadema antillarum Philippi. Can. J. Zool. 42: 549-557

Menge, B. A. (1976). Organization of the New England rocky intertidal community: role of predation, competition, and environmental heterogeneity. Ecol. Monogr. 46(4): 355-393

Montgomery, W. L. (1980a). Comparative feeding ecology of two herbivorous damselfishes (Pomacentridae: Teleostei) from the Gulf of California, Mexico. J. exp. mar. Biol. Ecol. $47 \cdot 9-24$

Montgomery, W. L. (1980b). The impact of non-selective grazing by the giant blue damselfish, Microspathodon dorsalis, on algal communities in the Gulf of California, Mexico. Bull. mar. Sci. 30: 290-303

Myrberg, A. A., Jr. (1972). Ethology of the bicolor damselfish, Eupomacentrus partitus (Pisces: Pomacentridae): a comparative analysis of laboratory and field behavior Anim. Behav. Monogr. Pt. 3, Vol. 5.: 1-293

Myrberg, A. A., Jr., Thresher, R. E. (1974). Interspecific aggression and its relevance to the concept of territoriality in reef fishes. Am. Zool. 14: 81-96

Ogden, J. C., Abbott, D. P., Abbott, I. (eds.) (1973a). Studies on the activity and food of the echinoid Diadema antillarum Philippi on a West Indian patch reef. West Indies Lab. Fairleigh Dickinson Univ., Spec. Publ. No. 2; 1-96

Ogden, J. C., Brown, R. A., Salesky, N. (1973b). Grazing by the echinoid Diadema antillarum Philippi: Formation of halos around West Indian patch reefs. Science, N. Y 182 (4113): 715-717

Ogden, J. C., Lobel, P. S. (1978). The role of herbivorous fishes and urchins in coral reef communities. Env. Biol. Fish 3(1): 49-63

Pearson, D. L. (1977). A pantropical comparison of bird community structure on six lowland forest sites. Condor $79(2)$ $232-244$

Pielou, E. C. (1967). The use of information theory in the study of biological populations. Proc. 5th Berkeley Symp. Math. Stat. Probability, Univ. Calif., Berkeley, 1965-1966, 4 163-177

Pielou, E. C. (1969). An introduction to mathematical ecology, Wiley, New York

Pielou, E. C. (1975). Ecological diversity, Wiley Interscience, Wiley, New York

Potts, D. C. (1977). Suppression of coral populations by filamentous algae within damselfish territories. J. exp. mar Biol. Ecol. 28(3): 207-216

Randall, J. E. (1967). Food habits of reef fishes of the West Indies. Stud. Trop. Oceanogr. 5: 665-847.

Randall, J. E., Schroeder, R. E., Stark, W. A. (1964). Notes on the biology of the echinoid Diadema antillarum. Caribb. J. Sci. 4: 421-433

Robertson, D. R., Sweatman, H. P. A., Fletcher, E. A., Cleland, M. G. (1976). Schooling as a mechanism for circumventing the territoriality of competitors. Ecology 57(6): 1208-1220

Sale, P. F. (1975). Patterns of use of space in a guild of territorial reef fishes. Mar Biol. 29: 89-97

Sammarco, P. W. (1972). Some aspects of the ecology of Diadema antillarum Philippi: food preference and effect of grazing. Special Problems Report to the West Indies Laboratory of Fairleigh Dickinson University, Christiansted, St. Croix

Sammarco, P. W. (1975). Grazing by Diadema antillarum Philippi (Echinodermata: Echinoidea): density-dependent effects on coral and algal community structure. Assoc. Isl., 
Mar. Labs. Caribb., Christianstead, St. Croix. U.S.V.I. 11. 19

Sammarco, P. W. (1977). The effects of grazing by Diadema antillarum Philippi on a shallow-water coral reef community. Ph.D. dissertation, Department of Ecology and Evolution, State University of New York at Stony Brook

Sammarco, P. W (1980a). Diadema and its relationship to coral spat mortality: grazing, competition, and biological disturbance. J. exp. mar Biol. Ecol. 45: 245-272

Sammarco, P. W. (1980b). The effects of damselfish territoriality on coral diversity and community structure. Aust. mar. Sci. Bull. 71: 22-23

Sammarco, P. W. (in press). Echinoid grazing as a structuring force in coral communities: whole reef manipulations. J. exp. mar. Biol. Ecol.

Sammarco, P. W., Carleton, J. H. (in press). Damselfush territoriality and coral community structure: reduced grazing and effects on coral spat. In: Gomez, E. (ed.) The reef and man., Proc. Fourth Int. Coral Reef Symp., Manila, May 1981

Sammarco, P. W., Levinton, J. S., Ogden, J. C. (1974). Grazing and control of coral reef community structure by Diadema antillarum Philippi (Echinodermata: Echinoidea): a preliminary study. J. mar. Res. 32(1): 47-53

Smith, D. P. B. (1975). Studies on sea urchins: I. Movement and behavior of the long-spined Caribbean sea urchin Diadema antillarum. Ph.D. dissertation, University of Wisconsin, Madison, Wisc.
Snyder, N., Snyder, H. (1970). Alarm responses of Diadema antillarum. Science, N.Y 168(3928): 276-278

Vance, R. R. (in press). Effects of grazing by the sea urchin, Centrostephanus coronatus, on prey community composition. Ecology

Vine, P. J. (1974). Effects of algal grazing and aggressive behavior of fishes Pomacentrus lividus and Acanthurus sohal on coral reef ecology. Mar. Biol. 24: 131-136

Whittaker, R. H., Levin, S. A. (1977). The role of mosaic phenomena in natural communities. Theor Popul. Biol. 12(2): $117-139$

Wilkinson, C. R., Sammarco, P. W. (in press). Nitrogen fixation on a coral reef: effects of fish grazing and damselfish territoriality. In: Gomez, E. (ed.) The reef and man. Proc. Fourth Int. Coral Reef Symp., Manila, May 1981

Williams, A. H. (1977). Three-way competition in a patchy back-reef environment. Ph.D. thesis, University of North Carolina, Chapel Hill

Williams, A. H. (1978). Ecology of threespot damselfish: social organization, age structure, and population stability. J. exp. mar. Biol. Ecol. 34: 197-213

Williams, A. H. (1979). Interference behavior and ecology of threespot damselfish (Eupomacentrus planifrons). Oecologia 38: 223-230

Williams, A. H. (1980). The threespot damselfish: a noncarnivorous keystone species. Am. Nat. 116(1): 138-142

Williams, A. H. (1981). An analysis of competitive interactions in a patchy back-reef environment. Ecology 62: 1107-1120

This paper was presented by Dr. J. S. Bunt; it was accepted for printing on December 8, 1981 